\title{
1,3- $\beta$-Glucan affects the balance of Th1/Th2 cytokines by promoting secretion of anti-inflammatory cytokines in vitro
}

\author{
YING CHEN, LEI DONG, DONG WENG, FANGWEI LIU, LAIYU SONG, CUIYING LI, WEN TANG and JIE CHEN
}

\begin{abstract}
Division of Pneumoconiosis, School of Public Health, China Medical University, Shenyang, Liaoning 110001, P.R. China
\end{abstract}
Received February 2, 2013; Accepted June 18, 2013

DOI: $10.3892 / \mathrm{mmr} .2013 .1553$

\begin{abstract}
. 1,3- $\beta$-glucan is considered a fungal biomarker and exposure to this agent induces lung inflammation. Previous studies have shown that 1,3- $\beta$-glucan affects Th1 and Th2 immune responses. Interleukin (IL)-10 and transforming growth factor (TGF)- $\beta$, as typical anti-inflammatory cytokines, suppress the Th1 immune response. To investigate the effects of 1,3- $\beta$-glucan on the secretion of cytokines in co-cultured mouse macrophages and lymphocytes in vitro, mice were exposed to 1,3- $\beta$-glucan or phosphate-buffered saline (PBS) by intratracheal instillation. Following extraction and co-culture of macrophages and lymphocytes, which were treated with or without 1,3- $\beta$-glucan in vitro, enzyme-linked immunosorbent assay (ELISA) was used to detect the levels of cytokines and real-time reverse transcription (RT)-polymerase chain reaction (PCR) was used to investigate the mRNA expression of forkhead box p3 (Foxp3) in the cells. We showed that 1,3- $\beta$-glucan exposure in vitro decreased the secretion of Th1 cytokines and increased the secretion of Th2 cytokines in the culture media. Furthermore, 1,3- $\beta$-glucan exposure in vitro increased the secretion of IL-10 and TGF- $\beta$ in the culture media. According to these results, $1,3-\beta$-glucan exposure in vitro is suggested to promote the secretion of anti-inflammatory cytokines, which may lead to a decrease in the levels of Th1 cytokines and an increase in the levels of Th2 cytokines. 1,3- $\beta$-Glucan is suggested to induce regulatory lymphocytes, which partly contributes to an increased secretion of anti-inflammatory cytokines in co-cultured mouse macrophages and lymphocytes in vitro.
\end{abstract}

\section{Introduction}

Organic dust is the dried particles of plants, animals, fungi or bacteria that are capable of being windborne due to their

Correspondence to: Dr Jie Chen or Dr Ying Chen, Division of Pneumoconiosis, School of Public Health, China Medical University, 92 North 2nd Road, Heping, Shenyang, Liaoning 110001, P.R. China E-mail: chenjie@mail.cmu.edu.cn

E-mail: chenying@mail.cmu.edu.cn

Key words: 1,3- $\beta$-glucan, Th1/Th2 cytokine, anti-inflammatory cytokine fine structure. Organic dust is commonly found in a large number of occupational and agricultural production environments $(1,2)$. Exposure to organic dust may cause several types of inflammatory lung disease, such as asthma and hypersensitivity pneumonitis (HP) $(2,3)$. The etiology of HP in organic dust processing environments includes numerous types of extrinsic substances. Fungi are known to constitute one of the main pathogenic causes of HP. 1,3- $\beta$-Glucan is a biomarker of fungi exposure and a major cell wall component of fungi (4-6). A strong association between the level of 1,3- $\beta$-glucan and respiratory symptoms has been reported previously (7).

Many studies have shown that $1,3-\beta$-glucan affects the Th1 immune response in different ways. Berner et al (8) showed that the synergy between interferon- $\gamma($ IFN- $\gamma)$ and 1,3 - $\beta$-glucan upregulates the mRNA expression of tumor necrosis factor (TNF)- $\alpha$, interleukin (IL)- 6 and IL-1 $\beta$, as well as the secretion of these pro-inflammatory cytokines in mouse peritoneal macrophages in vitro. Furthermore, a number of studies have shown that dietary $1,3-\beta$-glucan increases the production of IL-12 and IFN- $\gamma$ from splenocytes, as well as the number of IFN- $\gamma$-producing cells $(9,10)$. However, Wu et al (11) demonstrated that dietary supplementation with 1,3- $\beta$-glucan significantly inhibited the delayed-type Th1 immune reaction (11). According to an additional study (12), 1,3 - $\beta$-glucan was suggested to have a beneficial action on restoring Th2 function. Th1 and Th2 cytokines were found to counteract each other. It was reported that some $1,3-\beta$-glucan inhibited the Th1 immune response (13). 1,3- $\beta$-Glucan could increase the levels of IL-10 and transforming growth factor- $\beta$ (TGF- $\beta$ ) to suppress the Th1 immune response $(12,14)$.

The aim of the present study was to investigate whether 1,3 - $\beta$-glucan affected the pattern of Th1 and Th2 cytokine secretion and regulated the Th1/Th2 balance by secreting anti-inflammatory cytokines. Therefore, macrophages and lymphocytes were extracted from mice and co-cultured in vitro. Enzyme-linked immunosorbent assay (ELISA) was used to detect the levels of cytokines in co-culture media and real-time reverse transcription (RT)-polymerase chain reaction (PCR) was used to determine the mRNA expression of forkhead box p3 (Foxp3) in lymphocytes.

\section{Materials and methods}

Animals. Healthy, female C57BL/6 mice (6-8 weeks old) were purchased from the SLAC Laboratory Animal Co., Ltd. 
(Shanghai, China). All of the animals were housed in a specific pathogen-free environment and maintained on standard mouse chow with free access to food and water. The study was approved by the Animal Care and Use Committee of the China Medical University (Shenyang, Liaoning, China; permit no. CMU62043010), and complied with the National Institute of Health Guide for the Care and Use of Laboratory Animals.

\section{1,3- $\beta$-Glucan exposure. Zymosan A from Saccharomyces} cerevisiae (Z4250), purchased from Sigma-Aldrich Inc. (St. Louis, MO, USA), was dissolved in phosphate-buffered saline (PBS) to a final concentration of $3 \mathrm{mg} / \mathrm{ml}$. Twenty mice were randomly allocated into two groups: the PBS and the 1,3- $\beta$-glucan group. All of the animals were anesthetized by an intraperitoneal injection of $2 \%$ pentobarbital sodium ( $45 \mathrm{mg} / \mathrm{kg}$ body weight). The trachea was exposed by opening the neck skin and blunt dissection. A 7-gauge needle was inserted transorally into the trachea. The mice in the 1,3- $\beta$-glucan or the PBS group were administered $0.1 \mathrm{ml}$ zymosan solution $(3 \mathrm{mg} / \mathrm{ml})$ or $0.1 \mathrm{ml}$ sterile PBS, respectively. The site of surgery was sutured and cleaned with penicillin. The mice were allowed to recover until they were sacrificed.

Macrophage isolation. All of the mice were sacrificed 7 days following exposure to 1,3- $\beta$-glucan (Zymosan A) or PBS. The lungs were removed and washed twice in cold PBS. Bronchoalveolar lavage fluid (BALF) was obtained by cannulating the trachea, injecting and retrieving $1-\mathrm{ml}$ aliquots of sterile physiological saline several times to obtain $6 \mathrm{ml}$ liquid. The BALF was centrifuged at $200 \mathrm{x}$ g for $8 \mathrm{~min}$ at $4{ }^{\circ} \mathrm{C}$; the pellet was washed and re-suspended with $0.5 \mathrm{ml}$ RPMI-1640. Cell suspension $(10 \mu \mathrm{l})$ was used to count the cells under a microscope. RPMI-1640 supplemented with $10 \%$ heat-inactivated fetal bovine serum (FBS) was then added to a final concentration of $1 \times 10^{5}$ cells $/ \mathrm{ml}$. BALF cells from mice in the PBS group were placed in 24-well tissue culture plates (Costar) in four wells. The plates were then placed in an incubator supplemented with $5 \% \mathrm{CO}_{2}$ at $37^{\circ} \mathrm{C}$. Macrophages were allowed to adhere for $2 \mathrm{~h}$, and the wells were then washed with RPMI-1640 thrice to rinse away most non-adherent cells.

Lymphocyte isolation. The spleens were removed from the mice and placed on 35- $\mathrm{mm}$ plates with 4-5 ml mouse lymphocyte separation medium (EZ-Sep ${ }^{\mathrm{TM}}$ Mouse 1X). After being grinded and mechanically disrupted, the splenocytes were isolated and carefully transferred to a $15-\mathrm{ml}$ centrifuge tube and covered with 200-500 $\mu \mathrm{l}$ RPMI-1640. Following centrifugation for $30 \mathrm{~min}$ at $360 \mathrm{x} \mathrm{g}$, lymphocytes were obtained and washed once with RPMI-1640 supplemented with 10\% FBS by centrifugation, followed by re-suspension in RPMI-1640. The cells were counted using a hemocytometer. Subsequently, cell concentration was adjusted to $5 \times 10^{6}$. Lymphocytes $(1 \mathrm{ml})$ from mice treated with PBS were transferred to the four wells containing macrophages.

Co-culture in vitro. Lymphocytes were cultured in 24-well flat-bottom plates pre-coated with macrophages. Macrophages from mice treated with PBS were the same in the four experimental groups. The four experimental groups were the following: the $\mathrm{LG}^{-} \mathrm{G}^{-}, \mathrm{LG}^{-} \mathrm{G}^{+}, \mathrm{LG}^{+} \mathrm{G}^{-}$and $\mathrm{LG}^{+} \mathrm{G}^{+}$group. $\mathrm{LG}^{-}$, lymphocytes isolated from PBS-treated mice; $\mathrm{LG}^{+}$, lymphocytes isolated from 1,3- $\beta$-glucan-treated mice; $\mathrm{G}^{-}$, lymphocytes co-cultured in vitro and treated with PBS; and $\mathrm{G}^{+}$, lymphocytes co-cultured in vitro treated with $1,3-\beta$-glucan $(100 \mu \mathrm{g} / \mathrm{ml})$. Each group contained ConA to stimulate survival. The cells were cultured for 24 or $48 \mathrm{~h}$ at $37^{\circ} \mathrm{C}$ under a $5 \% \mathrm{CO}_{2}$ atmosphere.

Separating and conserving. Following 24 or $48 \mathrm{~h}$ of culture, mixtures of cells and culture media were transferred to $1.5-\mathrm{ml}$ Eppendorf tubes, followed by centrifugation for $8 \mathrm{~min}$ at $4^{\circ} \mathrm{C}$. Subsequently, culture media were stored for the investigation of cytokine protein levels. TRIzol reagent was added to the lymphocytes to avoid RNA degradation. The cells and culture media were maintained at $-70^{\circ} \mathrm{C}$.

Enzyme-linked immunosorbent assay (ELISA). The ELISA plate was coated with $100 \mu \mathrm{l}$ capture antibody in coating buffer/well of the ELISA kit (eBioscience, San Diego, CA, USA) and incubated at $4^{\circ} \mathrm{C}$ overnight. The plate was washed with $250 \mu \mathrm{l}$ washing buffer. The cells in each well were then blocked with $200 \mu \mathrm{l}$ assay diluent and incubated for $1 \mathrm{~h}$ at room temperature. A volume of $100 \mu$ l culture supernatants or the different dilutions of standard (for standard curve) were added to each well and incubated for $2 \mathrm{~h}$ at room temperature. The cells in each well were incubated with $100 \mu$ l detection antibody for $1 \mathrm{~h}$ at room temperature, followed by incubation with $100 \mu \mathrm{l}$ avidin-HRP for $30 \mathrm{~min}$ at room temperature. Substrate solution $(100 \mu \mathrm{l})$ was added to each well for a 15 -min incubation at room temperature. Stop solution $(50 \mu \mathrm{l})$ was added to stop the reaction. The absorbance was read at $450 \mathrm{~nm}$. ELISA was performed in triplicate.

RNA extraction and real-time RT-PCR. Total RNA was extracted from lymphocytes using the TRIzol reagent (Invitrogen Life Technologies, Carlsbad, CA, USA) according to the manufacturer's protocol. The RNA concentration and the ratio of $\mathrm{A} 260 / 280$ were determined using an ultraviolet (UV) spectrophotometer. The primers were designed using Primer3 (http://frodo.wi.mit.edu/primer3) and the sequences were blasted (http://blast.ncbi.nlm.nih.gov/Blast.cgi). PrimeScript RT reagent kit (DRR037A; Takara, Shiga, Japan) and SYBR Premix Ex Taq II (DRR081A; Takara) were used for real-time RT-PCR. The primer sequences used were the following:Foxp3,sense 5'-CAGCTCTGCTGGCGAAAGTG-3' and antisense, 5'-TCGTCTGAAGGCAGAGTCAGGA-3'; GAPDH, sense, 5'-CAATGTGTCCGTCGTGGATCT-3' and antisense, 5'-GTCCTCAGTGTAGCCCAAGATG-3'. Total RNA $(0.4 \mu \mathrm{g})$ of each group at $48 \mathrm{~h}$ was reverse transcribed in a volume of $20 \mu \mathrm{l}$ and the following PCR conditions were used: $37^{\circ} \mathrm{C}$ for $15 \mathrm{~min}$ and $85^{\circ} \mathrm{C}$ for $5 \mathrm{sec}$. cDNA $(2 \mu \mathrm{l})$ was used in a $25-\mu 1$ PCR reaction volume. Each sample was assayed in triplicate. The difference of the amplification efficiency between the target gene and the housekeeping gene were identified by comparing the slopes of the standard curves. The PCR reactions were run on ABI 7500 (Applied Biosystems) using the following conditions: $95^{\circ} \mathrm{C}$ for $30 \mathrm{sec}$, and 40 cycles of $95^{\circ} \mathrm{C}$ for $5 \mathrm{sec}$ and $60^{\circ} \mathrm{C}$ for $34 \mathrm{sec}$. Analysis was performed using the ABI 7500 system software. 
Statistical analysis. The SPSS 16.0 software was used to perform statistical analyses. The differences between values were evaluated using one-way analysis of variance (ANOVA) followed by pair-wise comparison with the LSD and Student-Newman-Keuls test. $\mathrm{P}<0.05$ was considered to indicate a statistically significant difference. All of the experiments were repeated five times. The results were expressed as the means \pm SEM.

\section{Results}

1,3- $\beta$-Glucan exposure decreases the secretion of Th1 cytokines in vitro. To investigate the role of $1,3-\beta$-glucan in the secretion of Th1 cytokines, macrophages isolated from mice treated with PBS were allocated into 4 groups. The levels of Th1 cytokines (IL-2 and IFN- $\gamma$ ) in the culture media of cells treated with $1,3-\beta$-glucan in vitro ( $\mathrm{LG}^{-} \mathrm{G}^{+}$group) significantly decreased compared with the $\mathrm{LG}^{-} \mathrm{G}^{-}$group 24 and $48 \mathrm{~h}$ following in vitro treatment (Figs. 1 and 2). The levels of IL-2 in the culture media of cells in the $\mathrm{LG}^{-} \mathrm{G}^{+}$and $\mathrm{LG}^{+} \mathrm{G}^{+}$groups significantly decreased compared with the $\mathrm{LG}^{-} \mathrm{G}^{-}$and $\mathrm{LG}^{+} \mathrm{G}^{-}$groups 24 and $48 \mathrm{~h}$ following treatment with 1,3- $\beta$-glucan or PBS in vitro (Fig. 1). The levels of IFN- $\gamma$ in the $\mathrm{LG}^{+} \mathrm{G}^{+}$group significantly decreased compared with the $\mathrm{LG}^{+} \mathrm{G}^{-}$group at both time points (Fig. 2).

The levels of IFN- $\gamma$ in the culture media of the cells treated with $1,3-\beta$-glucan in vivo ( $\mathrm{LG}^{+} \mathrm{G}^{-}$group) significantly increased compared with $\mathrm{LG}^{-} \mathrm{G}^{-}$and $\mathrm{LG}^{-} \mathrm{G}^{+}$groups $48 \mathrm{~h}$ following in vitro treatment (Fig. 2). The levels of IL-2 in the culture media of the cells treated with 1,3- $\beta$-glucan in vivo ( $\mathrm{LG}^{+} \mathrm{G}^{-}$group) significantly increased compared with $\mathrm{LG}^{-} \mathrm{G}^{-}$ and $\mathrm{LG}^{-} \mathrm{G}^{+}$group $24 \mathrm{~h}$ following in vitro treatment (Fig. 1). This suggests that $1,3-\beta$-glucan inhibits the secretion of Th1 cytokines in vitro.

1,3- $\beta$-Glucan exposure increases the secretion of the Th2 cytokine IL-4 in vitro. The secretion of the Th2 cytokine IL-4 in response to $1,3-\beta$-glucan treatment in vitro was examined. The levels of IL-4 increased in the culture media of the cells in the $\mathrm{LG}^{+} \mathrm{G}^{+}$group compared with the $\mathrm{LG}^{+} \mathrm{G}^{-}$group $24 \mathrm{~h}$ following in vitro treatment (Fig. 3). The levels of IL-4 in the culture media of the $\mathrm{LG}^{-} \mathrm{G}^{+}$and $\mathrm{LG}^{+} \mathrm{G}^{+}$groups increased compared with the $\mathrm{LG}^{-} \mathrm{G}^{-}$and $\mathrm{LG}^{+} \mathrm{G}^{-}$groups $48 \mathrm{~h}$ after treatment with 1,3- $\beta$-glucan or PBS in vitro (Fig. 3). This result suggests that $1,3-\beta$-glucan increases the expression levels of IL-4 in vitro.

\section{1,3- $\beta$-Glucan exposure promotes the secretion of} anti-inflammatory cytokines in vitro. The expression levels of anti-inflammatory cytokines were then assessed. The expression levels of IL-10 in the culture media of the $\mathrm{LGG}^{+}$ and $\mathrm{LG}^{+} \mathrm{G}^{+}$groups significantly increased compared with the $\mathrm{LG}^{-} \mathrm{G}^{-}$and $\mathrm{LG}^{+} \mathrm{G}^{-}$groups 24 and $48 \mathrm{~h}$ following in vitro treatment (Fig. 4). Thus, 1,3- $\beta$-glucan increases the secretion of IL-10 in vitro.

The expression levels of TGF- $\beta$ in the culture media of the $\mathrm{LG}^{+} \mathrm{G}^{+}$group increased compared with the $\mathrm{LG}^{+} \mathrm{G}^{-}$group at $24 \mathrm{~h}$. At $48 \mathrm{~h}$, the levels of TGF- $\beta$ in the $\mathrm{LG}^{-} \mathrm{G}^{+}$and $\mathrm{LG}^{+} \mathrm{G}^{+}$ groups increased compared with the $\mathrm{LG}^{-} \mathrm{G}^{-}$and $\mathrm{LG}^{+} \mathrm{G}^{-}$groups (Fig. 5). These results suggest that $1,3-\beta$-glucan alters the Th1/Th2 balance through an IL-10 dependent rather than an TGF- $\beta$-dependent pathway.

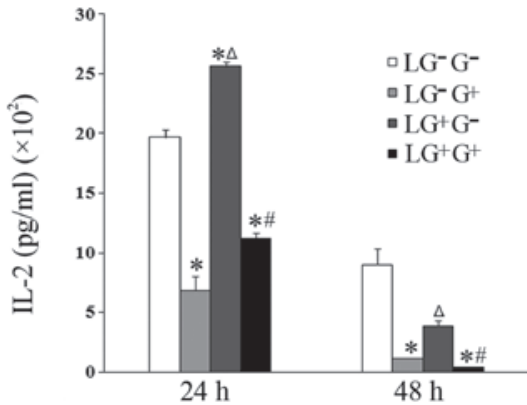

Figure 1. Levels of IL-2 in the culture media. The expression levels of IL-2 in the culture media were determined using ELISA ( $n=5)$. The levels of IL-2 in all the cell groups for the various treatment durations are shown in the graph. $\mathrm{LG}^{-} \mathrm{G}^{-}$group, lymphocytes isolated from PBS-treated mice, co-cultured in vitro and treated with $\mathrm{PBS} ; \mathrm{LG}^{-} \mathrm{G}^{+}$group, lymphocytes isolated from PBS-treated mice, co-cultured in vitro and treated with $1,3-\beta$-glucan; $\mathrm{LG}^{+} \mathrm{G}$ group, lymphocytes isolated from $1,3-\beta$-glucan-treated mice, co-cultured in vitro and treated with $\mathrm{PBS} ; \mathrm{LG}^{+} \mathrm{G}^{+}$group, lymphocytes isolated from 1,3 - $\beta$-glucan-treated mice, co-cultured in vitro and treated with $1,3-\beta$-glucan. ${ }^{*} \mathrm{P}<0.05$ compared with the $\mathrm{LG}^{-} \mathrm{G}^{-}$group; ${ }^{\Delta} \mathrm{P}<0.05$ compared with the $\mathrm{LG}^{-} \mathrm{G}^{+}$ group; ${ }^{\text {P }}<0.05$ compared with the $\mathrm{LG}^{+} \mathrm{G}^{-}$group. IL, interleukin; ELISA, enzyme-linked immunosorbent assay; PBS, phosphate-buffered saline.

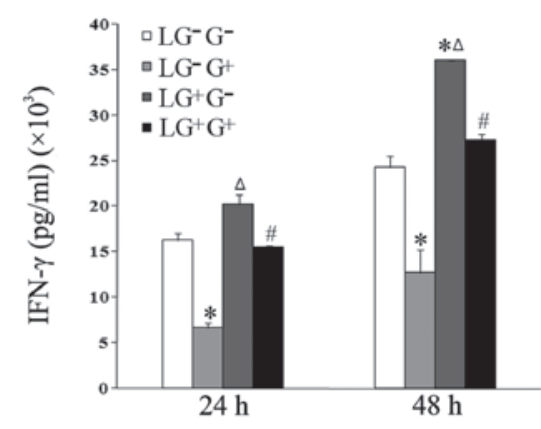

Figure 2. Levels of IFN- $\gamma$ in the culture media. The expression levels of IFN- $\gamma$ in the culture media were determined using ELISA $(n=5)$. The levels of IFN- $\gamma$ in all the cell groups for the various treatment durations are shown in the graph. $\mathrm{LG}^{-} \mathrm{G}^{-}$group, lymphocytes isolated from PBS-treated mice, co-cultured in vitro and treated with PBS; $\mathrm{LG}^{-} \mathrm{G}^{+}$group, lymphocytes isolated from PBS-treated mice, co-cultured in vitro and treated with 1,3 - $\beta$-glucan; $\mathrm{LG}^{+} \mathrm{G}^{-}$group, lymphocytes isolated from $1,3-\beta$-glucan-treated mice, co-cultured in vitro and treated with $\mathrm{PBS} ; \mathrm{LG}^{+} \mathrm{G}^{+}$group, lymphocytes isolated from 1,3- $\beta$-glucan-treated mice, co-cultured in vitro and treated with 1,3 - $\beta$-glucan. ${ }^{*} \mathrm{P}<0.05$ compared with the $\mathrm{LG}^{-} \mathrm{G}^{-}$group; ${ }^{\Delta} \mathrm{P}<0.05$ compared with the $\mathrm{LG}^{-} \mathrm{G}^{+}$group; ${ }^{\#} \mathrm{P}<0.05$ compared with the $\mathrm{LG}^{+} \mathrm{G}^{-}$group. IL, interleukin; ELISA, enzyme-linked immunosorbent assay; PBS, phosphatebuffered saline.

1,3- $\beta$-Glucan exposure may increase the expression of Foxp3 $m R N A$ in vitro. As shown in Fig. 6, although the mRNA expression of Foxp3 increased in response to 1,3- $\beta$-glucan treatment in vitro, no statistically significant difference among the 4 cell groups was observed. This result suggests that 1,3 - $\beta$-glucan exposure may increase the expression of Foxp3 in lymphocytes.

\section{Discussion}

Th1/Th2 balance is the major framework used to address adaptive immunity (15), and Th1 and Th2 cells are characterized by specific cytokine signatures (16). IL-2 and IFN- $\gamma$ are considered to be hallmark Th1 cytokines $(15,17,18)$, while 


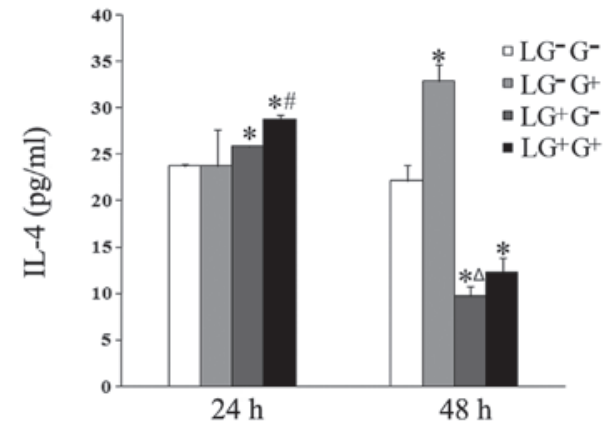

Figure 3. Levels of IL-4 in the culture media. The expression levels of IL-4 in the culture media were determined using ELISA $(n=5)$. The levels of IL-4 in all the cell groups for the various treatment durations are shown in the graph. LG $^{-}{ }^{-}$group, lymphocytes isolated from PBS-treated mice, co-cultured in vitro and treated with PBS; $\mathrm{LG}^{-} \mathrm{G}^{+}$group, lymphocytes isolated from PBS-treated mice, co-cultured in vitro and treated with $1,3-\beta$-glucan; $\mathrm{LG}^{+} \mathrm{G}$ group, lymphocytes isolated from 1,3- $\beta$-glucan-treated mice, co-cultured in vitro and treated with $\mathrm{PBS} ; \mathrm{LG}^{+} \mathrm{G}^{+}$group, lymphocytes isolated from $1,3-\beta$-glucan-treated mice, co-cultured in vitro and treated with $1,3-\beta$-glucan. ${ }^{*} \mathrm{P}<0.05$ compared with the $\mathrm{LG}^{-} \mathrm{G}^{-}$group; ${ }^{\wedge} \mathrm{P}<0.05$ compared with the $\mathrm{LG}^{-} \mathrm{G}^{+}$ group; ${ }^{\prime} \mathrm{P}<0.05$ compared with the $\mathrm{LG}^{+} \mathrm{G}^{-}$group. IL, interleukin; ELISA, enzyme-linked immunosorbent assay; PBS, phosphate-buffered saline.

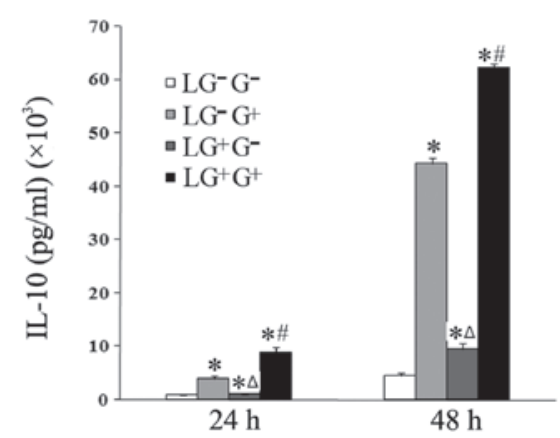

Figure 4. Levels of IL-10 in the culture media. The expression levels of IL-10 in the culture media were determined using ELISA $(n=5)$. The levels of IL-10 in all the cell groups for the various treatment durations are shown in the graph. $\mathrm{LG}^{-} \mathrm{G}^{-}$group, lymphocytes isolated from PBS-treated mice, co-cultured in vitro and treated with PBS; $\mathrm{LG}^{-} \mathrm{G}^{+}$group, lymphocytes isolated from PBS-treated mice, co-cultured in vitro and treated with $1,3-\beta$-glucan; $\mathrm{LG}^{+} \mathrm{G}$ group, lymphocytes isolated from 1,3- $\beta$-glucan-treated mice, co-cultured in vitro and treated with $\mathrm{PBS} ; \mathrm{LG}^{+} \mathrm{G}^{+}$group, lymphocytes isolated from $1,3-\beta$-glucan-treated mice, co-cultured in vitro and treated with $1,3-\beta$-glucan. ${ }^{*} \mathrm{P}<0.05$ compared with the LG-G' group; ${ }^{\circ} \mathrm{P}<0.05$ compared with the $\mathrm{LG}^{-} \mathrm{G}^{+}$ group; ${ }^{\text {}} \mathrm{P}<0.05$ compared with the $\mathrm{LG}^{+} \mathrm{G}$ group. IL, interleukin; ELISA, enzyme-linked immunosorbent assay; PBS, phosphate-buffered saline.

IL-4 is the hallmark Th2 cytokine. Many studies have demonstrated that the secretion of pro-inflammatory cytokines is upregulated in macrophages exposed to soluble or particulate $\beta$-glucans $(8,19-22)$. In the present study, macrophages and lymphocytes were extracted from mice and co-cultured in vitro in order to investigate the role of 1,3- $\beta$-glucan in Th1/Th2 balance. According to our results, the expression of Th1 cytokines, such as IFN- $\gamma$ and IL-2, was inhibited, while the expression of the Th2 cytokine IL-4 was increased following 1,3 - $\beta$-glucan stimulation. Moreover, 1,3- $\beta$-glucan exposure in vitro increased the secretion of IL-10 and TGF- $\beta$ in the culture media of cells. These results suggest that $1,3-\beta$-glucan may alter the Th1/Th2 balance towards a Th2-dependent response by promoting the secretion of anti-inflammatory cytokines.

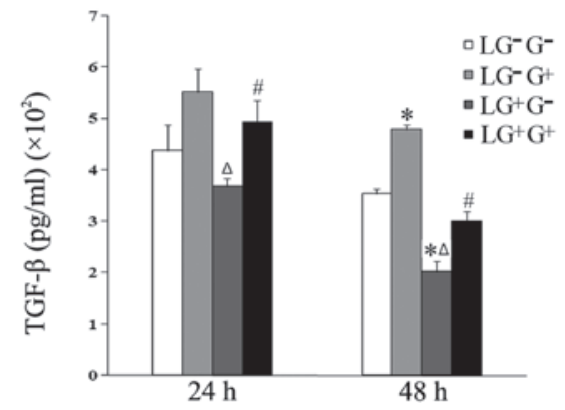

Figure 5. Levels of TGF- $\beta$ in the culture media. The expression levels of TGF- $\beta$ in the culture media were determined using ELISA $(n=5)$. The levels of TGF- $\beta$ in all the cell groups for the various treatment durations are shown in the graph. $\mathrm{LG}^{-} \mathrm{G}^{-}$group, lymphocytes isolated from PBS-treated mice, co-cultured in vitro and treated with PBS; $\mathrm{LG}^{-} \mathrm{G}^{+}$group, lymphocytes isolated from PBS-treated mice, co-cultured in vitro and treated with 1,3- $\beta$-glucan; $\mathrm{LG}^{+} \mathrm{G}^{-}$group, lymphocytes isolated from 1,3 - $\beta$-glucan-treated mice, co-cultured in vitro and treated with $\mathrm{PBS} ; \mathrm{LG}^{+} \mathrm{G}^{+}$group, lymphocytes isolated from 1,3- $\beta$-glucan-treated mice, co-cultured in vitro and treated with 1,3 - $\beta$-glucan. ${ }^{*} \mathrm{P}<0.05$ compared with the $\mathrm{LG}^{-} \mathrm{G}^{-}$group; ${ }^{\Delta} \mathrm{P}<0.05$ compared with the $\mathrm{LG}^{-} \mathrm{G}^{+}$group; ${ }^{\sharp} \mathrm{P}<0.05$ compared with the $\mathrm{LG}^{+} \mathrm{G}^{-}$group. TGF- $\beta$, transforming growth factor- $\beta$; ELISA, enzyme-linked immunosorbent assay; PBS, phosphate-buffered saline.

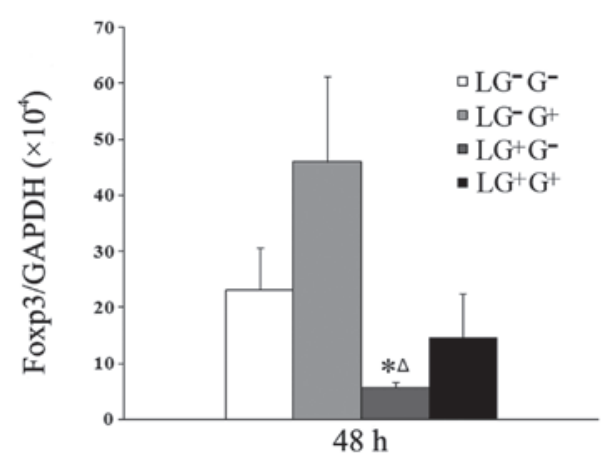

Figure 6. Levels of Foxp3 mRNA expression in lymphocytes. The expression of Foxp3 mRNA at $48 \mathrm{~h}$ was assessed by real-time RT-PCR using the $-\Delta \Delta \mathrm{Ct}$ method $(\mathrm{n}=5)$. The levels of Foxp3 mRNA expression in all the cell groups $48 \mathrm{~h}$ following in vitro treatment are shown in the graph. LG-G' group, lymphocytes isolated from PBS-treated mice, co-cultured in vitro and treated with PBS; $\mathrm{LG}^{-} \mathrm{G}^{+}$group, lymphocytes isolated from PBS-treated mice, co-cultured in vitro and treated with 1,3- $\beta$-glucan; $\mathrm{LG}^{+} \mathrm{G}^{-}$group, lymphocytes isolated from 1,3- $\beta$-glucan-treated mice, co-cultured in vitro and treated with PBS; $\mathrm{LG}^{+} \mathrm{G}^{+}$group, lymphocytes isolated from $1,3-\beta$-glucan-treated mice, co-cultured in vitro and treated with $1,3-\beta$-glucan. ${ }^{*} \mathrm{P}<0.05$ compared with the $\mathrm{LG}^{-} \mathrm{G}^{-}$group; ${ }^{\wedge} \mathrm{P}<0.05$ compared with the $\mathrm{LG}^{-} \mathrm{G}^{+}$group. Foxp3, forkhead box $\mathrm{p} 3$; PBS, phosphate-buffered saline.

IL-10 and TGF- $\beta$ are considered as anti-inflammatory cytokines $(23,24)$. In the present study, the expression of these two anti-inflammatory cytokines increased when the cells were treated with $1,3-\beta$-glucan in vitro, which was consistent with the results of previous studies $(12,24,25)$. In response to antigen stimulation, naive lymphocytes may differentiate into regulatory lineages which could regulate the $\mathrm{Th} 1 / \mathrm{Th} 2$ balance via IL-10 and/or TGF- $\beta$ (26-28). Foxp3 plays an important role in the development and function of regulatory lymphocytes. In the present study, the increased tendency of Foxp3 upon 1,3- $\beta$-glucan stimulation suggested that regulatory $\mathrm{T}$ or B cells may regulate the Th1/Th2 balance via IL-10 and/or TGF- $\beta$ (22). The underlying mechanism of action has yet to be fully elucidated. 
Antigen presentation cells (APC) which are able to initiate innate immunity, such as macrophages, express specific surface receptors, such as Dectin-1, to recognize 1,3- $\beta$-glucan $(29,30)$. These processed then initiated the adaptive immune responses, accompanied by the secretion of pro-inflammatory cytokines $(6,30,31)$. In the present study, macrophages were isolated from mice treated with 1,3- $\beta$-glucan, and co-cultured with lymphocytes in vitro. The results obtained were highly identical (data not shown). These data suggest that macrophages, which possess 1,3- $\beta$-glucan-binding sites on their cell surface, direct the differentiation of lymphocytes $(19,20)$.

The results of the present study showed that in vivo exposure to 1,3- $\beta$-glucan upregulated the secretion of the Th1 cytokines, IFN- $\gamma$ and IL-2. These cytokines corresponded to the early stage of inflammation in mice, which was Th1 dominant (22). According to our previous study, TGF- $\beta$ was reduced in the early stage of 1,3- $\beta$-glucan-induced inflammation (22). Exposure to $1,3-\beta$-glucan in vitro alone increased the secretion of TGF- $\beta$, while in vivo exposure to $1,3-\beta$-glucan led to a decrease in TGF- $\beta$ expression. TGF- $\beta$ may be secreted in the earliest phase and rapidly inhibited by increasing Th1 production in vivo.

In conclusion, the present study demonstrates that $1,3-\beta$-glucan exposure in vitro promotes the secretion of anti-inflammatory cytokines, leading to a decrease in Th1 and increase in Th2 cytokine expression. 1,3- $\beta$-Glucan is capable of inducing regulatory lymphocytes, which could partly contribute to an increased secretion of anti-inflammatory cytokines in co-cultured mouse macrophages and lymphocytes in vitro.

\section{Acknowledgements}

This study was supported by a grant from the National Natural Science Foundation of China (No. 30771791) and a Program for Liaoning Excellent Talents in University (No. LR201039).

\section{References}

1. Rylander R: Airborne (1-3)- $\beta$-D-glucan and airway disease in a day-care center before and after renovation. Arch Environ Health 52: 281-285, 1997.

2. Rylander R, Thorn J and Attefors R: Airways inflammation among workers in a paper industry. Eur Respir J 13: 1151-1157, 1999.

3. Ronald LA, Davies HW, Bartlett KH, et al: Beta(1-3)-glucan exposure levels among workers in four British Columbia sawmills. Ann Agric Environ Med 10: 21-29, 2003.

4. Rylander R: Investigations of the relationship between disease and airborne (1-3)-beta-D-glucan in buildings. Mediators Inflamm 6: 275-277, 1997.

5. Rylander R: Indoor air-related effects and airborne (1-3)-betaD-glucan. Environ Health Perspect 107 (Suppl 3): 501-503, 1999.

6. Brown GD and Gordon S: Fungal beta-glucans and mammalian immunity. Immunity 19: 311-315, 2003.

7. Rylander R and Lin RH: (1-3)-beta-D-glucan-relationship to indoor air-related symptoms, allergy and asthma. Toxicology 152: 47-52, 2000.

8. Berner MD, Sura ME, Alves BN and Hunter KW Jr: IFN-gamma primes macrophages for enhanced TNF-alpha expression in response to stimulatory and non-stimulatory amounts of microparticulate beta-glucan. Immunol Lett 98: 115-122, 2005.

9. Kimura Y, Sumiyoshi M, Suzuki T, Suzuki T and Sakanaka M: Inhibitory effects of water-soluble low-molecular-weight $\beta-(1,3-1,6)$ d-glucan purified from Aureobasidium pullulans GM-NH-1A1 strain on food allergic reactions in mice. Int Immunopharmacol 7: 963-972, 2007.
10. Xiao ZG, Trincado CA and Murtaugh MP: Beta-glucan enhancement of $\mathrm{T}$ cell IFNgamma response in swine. Vet Immunol Immunopathol 102: 315-320, 2004.

11. Wu HH, Weng BBC, Chen KL, Chiou PWS and Yu B: Effect of dietary supplementation of $\beta-1,3-1,6$-glucan on reproductive performance and immunity of New Zealand White does and their pups. Livest Sci 135: 70-75, 2011.

12. Sarinho E, Medeiros D, Schor D, et al: Production of interleukin-10 in asthmatic children after Beta-1-3-glucan. Allergol Immunopathol (Madr) 37: 188-192, 2009.

13. Zhou LD, Zhang QH, Zhang Y, Liu J and Cao YM: The shiitake mushroom-derived immuno-stimulant lentinan protects against murine malaria blood-stage infection by evoking adaptive immune-responses. Int Immunopharmacol 9: 455-462, 2009.

14. Olman MA and Matthay MA: Transforming growth factor- $\beta$ induces fibrosis in immune cell-depleted lungs. Am J Physiol Lung Cell Mol Physiol 285: L522-L526, 2003.

15. Mosmann TR and Coffman RL: TH1 and TH2 cells: different patterns of lymphokine secretion lead to different functional properties. Annu Rev Immunol 7: 145-173, 1989.

16. Wei WC, Su YH, Chen SS, Sheu JH and Yang NS: GM-CSF plays a key role in zymosan-stimulated human dendritic cells for activation of Th1 and Th17 cells. Cytokine 55: 79-89, 2011.

17. Coffman RL, Mocci S and O'Garra A: The stability and reversibility of Th1 and Th2 populations. Curr Top Microbiol Immunol 238: 1-12, 1999.

18. Mosmann TR, Cherwinski H, Bond MW, Giedlin MA and Coffman RL: Two types of murine helper T cell clone. I. Definition according to profiles of lymphokine activities and secreted proteins. J Immunol 136: 2348-2357, 1986.

19. Hoffman OA, Olson EJ and Limper AH: Fungal beta-glucans modulate macrophage release of tumor necrosis factor-alpha in response to bacterial lipopolysaccharide. Immunol Lett 37: 19-25, 1993.

20. Sakurai T, Ohno N and Yadomae T: Effects of fungal beta-glucan and interferon-gamma on the secretory functions of murine alveolar macrophages. J Leukoc Biol 60: 118-124, 1996.

21. Abel G and Czop JK: Stimulation of human monocyte beta-glucan receptors by glucan particles induces production of TNF-alpha and IL-1 beta. Int J Immunopharmacol 14: 1363-1373, 1992.

22. Liu FW, Weng D, Chen Y, et al: Depletion of CD $4^{+} \mathrm{CD} 25^{+} \mathrm{Foxp} 3^{+}$ regulatory $\mathrm{T}$ cells with anti-CD25 antibody may exacerbate the 1,3 - $\beta$-glucan-induced lung inflammatory response in mice. Arch Toxicol 85: 1383-1394, 2011.

23. Ding L and Shevach EM: IL-10 inhibits mitogen-induced T cell proliferation by selectively inhibiting macrophage costimulatory function. J Immunol 148: 3133-3139, 1992.

24. Young SH, Ye J, Frazer DG, Shi X and Castranova V: Molecular mechanism of tumor necrosis factor-alpha production in 1,3-beta-glucan (zymosan)-activated macrophages. J Biol Chem 276: 20781-20787, 2001.

25. Gantner BN, Simmons RM, Canavera SJ, Akira S and Underhill DM: Collaborative induction of inflammatory responses by dectin-1 and Toll-like receptor 2. J Exp Med 197: 1107-1117, 2003.

26. Li MO, Wan YY, Sanjabi S, Robertson AK and Flavell RA: Transforming growth factor-beta regulation of immune responses. Annu Rev Immunol 24: 99-146, 2006.

27. O'Garra A, Barrat FJ, Castro AG, Vicari A and Hawrylowicz C: Strategies for use of IL-10 or its antagonists in human disease. Immunol Rev 223: 114-131, 2008.

28. Moore KW, O'Garra A, de Waal Malefyt R, Vieira P and Mosmann TR: Interleukin-10. Annu Rev Immunol 11: 165-190, 1993.

29. Kankkunen P, Teiril L, Rintahaka J, Alenius H, Wolff H and Matikainen S: $(1,3)$-beta-glucans activate both dectin-1 and NLRP3 inflammasome in human macrophages. J Immunol 184: 6335-6342, 2010.

30. Li B, Cramer D, Wagner S, et al: Yeast glucan particles activate murine resident macrophages to secrete proinflammatory cytokines via MyD88- and Syk kinase-dependent pathways. Clin Immunol 124: 170-181, 2007.

31. Ganner A, Nitsch S, Erlacher K, Klimitsch A and Schatzmayr G: Ex vivo effect of yeast beta-glucan on lymphocyte viability and plasma IL-18 in weaning piglets. Livest Sci 133: 246-248, 2010. 